\title{
BATIK DESIGN TRAINING SEBAGAI UPAYA PEMBEKALAN SOFT SKILL DI BIDANG DESAIN GRAFIS TERHADAP SISWA-SISWI SMK NEGERI 5 KOTA BENGKULU
}

\section{BATIK DESIGN TRAINING AS AN EFFORT TO SOFT SKILL DEBRIEFING IN DESIGN GRAPHIC FOR SMK NEGERI 5 STUDENTS OF BENGKULU CITY}

\author{
Oleh: \\ Ernawati $^{1)}$, Funny Farady Coastera ${ }^{1)}$, dan Yuli Rodiah ${ }^{2)}$ \\ ${ }^{1)}$ Program Studi Teknik Infomatika, Fakultas Teknik, Universitas Bengkulu \\ ${ }^{2)}$ Program Studi Teknik Elektro, Fakultas Teknik, Universitas Bengkulu \\ w_ier_na@yahoo.com,ffaradyc@unib.ac.id
}

\begin{abstract}
Students of SMK Negeri 5 Bengkulu are given batik skills provision in Textile Craft Competence since 1995. The quality of students' batik production, especially batik Basurek, has been recognized nationally. Traditional batik skills can be coupled with insight into computer graphics. As the generations facing the global market, batik craftsmen are charged to be more creative using technology in developing their business. Implementation method of the community service program is the method of knowledge transfer to the students and applying the concept of graphic design by using Adobe Photoshop. Direct practice using the computer and debriefing between instructor and participants help participants in understanding of training material. Evaluation are conducted by comparing the results of observations before and after training. From the results of the evaluation we concluded that trainees are already able to understand the basic functions of the software Adobe Photoshop and using it to design batik.
\end{abstract}

Keywords: adobe photoshop, batik basurek, graphic design, senior high school student

\section{PENDAHULUAN}

Indonesia merupakan sebuah negara multikultur yang didalamnya terdapat suku bangsa yang beragam dengan keanekaragaman budaya yang dimilikinya. Salah satu warisan budaya bangsa Indonesia yang telah dicipta dan dikembangkan berbagai suku yang ada di Indonesia sejak zaman dahulu adalah budaya membatik. Keberadaan batik tidak hanya menjadi ciri budaya bangsa tetapi juga diakui secara internasional sebagai salah satu karya seni tradisi yang Adiluhung (bermutu tinggi). Organisasi PBB melalui United Nations Educational, Scientific and Cultural Organization (UNESCO) menetapkan secara resmi pada 2 Oktober 2009 di Abu Dhabi, bahwa batik sebagai salah satu warisan budaya dunia berasal dari Indonesia. Pengakuan dunia tentang batik sebagai warisan dunia diberikan berdasarkan penilaian terhadap nilai historis, filosofis dan keragaman ekspresi 
pada motif batik. Batik sebagai salah satu produk seni budaya bangsa Indonesia sekarang ini berkembang dengan baik dan memiliki daya tarik tersendiri bagi masyarakat dunia.

Batik basurek adalah ciri khas kerajinan daerah Bengkulu yang diwariskan dari generasi ke generasi dan pengembangan sektor usaha kecil menengah di Kota Bengkulu. Pemerintah Kota Bengkulu melakukan pembinaan terhadap usaha batik basurek yang tersisa untuk beroperasi dengan cara memberikan kemudahan baik dari sisi produk maupun pemasaran. Berdasarkan hasil penelitian 2009 diperoleh bahwa pengembangan SDM melalui pelatihan sudah pernah dilakukan, namun pelatihan yang diikuti oleh pengrajin batik basurek tidak sesuai dengan profesi yang ditekuni saat ini; pengembangan SDM melalui peningkatan pendidikan sudah pernah dilakukan; dan pengembangan SDM melalui pemberian informasi juga sudah pernah dilakukan, walaupun dirasakan sangat kurang.

Pendidikan menengah kejuruan mengutamakan penyiapan siswa untuk memasuki lapangan kerja serta mengembangkan sikap professional. Sesuai dengan bentuknya, sekolah menengah kejuruan menyelenggarakan program-program pendidikan yang disesuaikan dengan jenis-jenis lapangan kerja.

SMK memilki banyak program keahlian. Program keahlian yang dilaksanakan di SMK menyesuaikan dengan kebutuhan dunia kerja yang ada. Program keahlian pada jenjang SMK juga menyesuaikan pada permintaan masyarakat dan pasar. Siswa SMK Negeri 5 Bengkulu diberi bekal keterampilan batik dalam Kompetensi Kriya Tekstil sejak tahun 1995. Secara kualitas batik produksi siswa khususnya batik basurek sudah diakui tingkat nasional ((Anonim, 2013)). Keterampilan batik tradisional dapat ditambah dengan wawasan komputer grafis. Sebagai generasi yang akan menghadap pasar global, pengrajin batik dituntun lebih kreatif menggunakan teknologi dalam mengembangkan usahanya.

Usaha yang dapat dilakukan adalah pembinaan keterampilan desain grafis dengan komputer. Banyak program yang dapat ditawarkan dalam mendesain batik, sebagai langkah awal pemberikan pelatihan membuat desain batik menggunakan software desain grafis yaitu Adobe Photoshop dapat diterapkan. Perangkat lunak ini banyak digunakan oleh fotografer digital dan perusahaan iklan sehingga dianggap sebagai pemimpin pasar (market leader) untuk perangkat lunak pangolah gambar/foto. Penggunaan Adobe Photoshop dalam mendesain batik diharapkan akan menjadi nilai tambah lulusan SMK umumnya, terutama SMK Negeri 5 khususnya dalam menambah khasanah keilmuan dan dapat menjadi sarana penciptaan lapangan kerja. Pelatihan terhadap siswa SMK diperlukan untuk memberi nilai tambah pada keahlian siswa dalam melakukan keterampilan membuat batik.

\section{METODE PENGABDIAN}

Metode pelaksanaan pada program pengabdian masyarakat ini yaitu dengan metode transfer ilmu kepada pihak yang disuluh. Pelatihan dilakukan dengan memberikan materi dari modul yang telah disiapkan. Praktek dibutuhkan secara langsung dengan membawa siswa ke laboratorium komputer untuk menerapkan teori yang telah diajarkan. Dengan 
metode pendampingan langsung diharapkan siswa dapat lebih mudah mengerti dan menerapkan konsep desain grafis menggunakan Adobe Photoshop.

\section{Persiapan}

Adapun kegiatan-kegiatan yang dilakukan pada tahap persiapan yaitu:

1. Survey tempat pelaksanaan kegiatan

2. Pembuatan modul pelatihan pembuatan batik dengan photoshop

3. Instalasi Adobe Photoshop di laboratorium Teknik Informatika-UNIB

4. Perbanyak modul sesuai dengan jumlah peserta

\section{Pelaksanaan Kegiatan}

Kegiatan pengabdian dilaksanakan setelah semua perizinan dan persiapan peralatan selesai dilakukan. Kegiatan dilaksanakan di laboratorium computer Teknik Informatika. Dalam pelaksanaannya tutor akan menjelaskan tentang photoshop dan mencontohkan bagaimana mendesain batik. Kemudian siswa-siswi akan mempraktekkan langsung dikomputer. Siswa-siswi akan diberi modul untuk membantu mereka dalam mendesain batik dengan photoshop. Adapun silabus pelaksanaan kegiatan dapat dilihat pada Tabel 1.

Tabel 1. Silabus Materi Batik Desain

\begin{tabular}{|c|c|c|}
\hline Materi Pelatihan & Sub Pokok Bahasan & Pertemuan \\
\hline $\begin{array}{l}\text { Modul I Dasar-dasar } \\
\text { Photoshop }\end{array}$ & $\begin{array}{ll}\text { - } & \text { Memulai Adobe Photoshop } \\
\text { - } & \text { Komponen Lembar Kerja Adobe } \\
& \text { Photoshop } \\
\text { - } & \text { Membuat Kanvas Baru } \\
\end{array}$ & 2 jam \\
\hline $\begin{array}{l}\text { Modul II Teknik Dasar } \\
\text { Photoshop }\end{array}$ & $\begin{array}{ll}\text { - } & \text { Pewarnaan } \\
\text { - } & \text { Teknik Mewarnai dengan Brush Tool } \\
\text { - } & \text { Teknik Membuat Efek Teks } \\
\end{array}$ & 2 jam \\
\hline $\begin{array}{l}\text { Modul III Teknik Dasar } \\
\text { Menyeleksi Gambar }\end{array}$ & $\begin{array}{ll}\text { - } & \text { Jenis-jenis Selection Tool dan } \\
\text { Penggunaannya } \\
\text { - } \quad \text { Pen Tool dan Quick Mask Mode } \\
\text { - } \quad \text { Teknik Menghilangkan Background Foto }\end{array}$ & 2 jam \\
\hline $\begin{array}{l}\text { Modul IV Membuat Motif } \\
\text { Batik }\end{array}$ & $\begin{array}{ll}\text { - } & \text { Membuat Kanvas Baru dan } \\
\text { Menggunakan Garis Bantu } \\
\text { - } & \text { Memulai Membuat Bentuk Dasar } \\
\text { - } & \text { Memberikan Efek Menggunakan Layer } \\
& \text { Style } \\
\text { - } & \text { Merotasi dan Menduplikat } \\
\end{array}$ & 2 jam \\
\hline $\begin{array}{l}\text { Modul V Mendesain } \\
\text { Menjadi Pattern }\end{array}$ & $\begin{array}{ll} & \text { Menyiapkan Objek Tambahan } \\
\text { - } & \text { Menggeser Objek dengan Offset } \\
\end{array}$ & 2 jam \\
\hline $\begin{array}{l}\text { Modul VI Mendesain } \\
\text { Menjadi Pattern } \\
\text { (Lanjutan) }\end{array}$ & $\begin{array}{ll}\text { - } & \text { Uji Repeat Pattern } \\
\text { - } & \text { Membuat Desain Batik Menggunakan } \\
& \text { Shape Tool }\end{array}$ & 2 jam \\
\hline
\end{tabular}




\section{Evaluasi}

Tabel 2. Evaluasi

\begin{tabular}{lll}
\hline \multicolumn{1}{c}{ Kriteria } & Indikator Pencapaian Tujuan & \multicolumn{1}{c}{ Tolak Ukur } \\
\hline $\begin{array}{l}\text { Pengetahuan } \\
\text { perkembangan desain } \\
\text { dengan komputer }\end{array}$ & $\begin{array}{l}\text { Siswa dapat menggunakan } \\
\text { sarana internet untuk meng- } \\
\text { update informasi mengenai } \\
\text { keterampilan membatik }\end{array}$ & $\begin{array}{l}\text { Evaluasi awal dan akhir } \\
\text { pelatihan }\end{array}$ \\
\hline $\begin{array}{l}\text { Keterampilan mendesain } \\
\text { batik dengan adobe } \\
\text { photoshop }\end{array}$ & $\begin{array}{l}\text { Siswa dapat menggunakan } \\
\text { adobe photoshop dalam }\end{array}$ & $\begin{array}{l}\text { Hasil ujian praktek } \\
\text { pelatihan }\end{array}$ \\
\hline
\end{tabular}

\section{HASIL DAN PEMBAHASAN}

\section{Hasil Pelaksanaan Kegiatan PPM}

Kegiatan program PPM ini adalah berupa pelatihan dan telah dilaksanakan pada hari Minggu, tanggal 28 September 2014, yang bertempat di Laboratorium Teknik Informatika Fakultas Teknik Universitas Bengkulu, yang beralamat di Jalan WR. Supratman Kandang Limun. Kegiatan tersebut dimulai dari pukul 09.00 WIB sampai dengan 15.00 WIB. Di dalam kegiatan pelatihan tersebut dibuka oleh ketua pelaksana kegiatan pengabdian yaitu Ibu Ernawati, S.T., M.Cs. Selanjutnya jumlah peserta yang hadir dalam kegiatan pelatihan tersebut adalah siswa-siswi SMK Negeri 5 Kota Bengkulu, di mana yang hadir dalam kegiatan tersebut berjumlah 25 orang.

Kegiatan PPM ini berjalan lancar. Peserta mengikuti seluruh rangkaian acara kegiatan dari awal sampai akhir. Materi yang disampaikan dapat dipahami oleh peserta dengan baik. Selanjutnya antusiasme dari para peserta dalam pelaksanaan kegiatan PPM ini ditunjukkan dengan adanya interaksi dan tanya jawab pada setiap sesinya yaitu antara 2-3 orang peserta.

\section{Pembahasan Hasil Kegiatan PPM}

Rancangan penilaian keberhasilan atau kegagalan dalam kegiatan PPM tentang "Batik Design Training Sebagai Upaya Pembekalan Soft Skill di Bidang Desain Grafis Terhadap Siswa-Siswi SMK Negeri 5 Kota Bengkulu" ini dilaksanakan dengan melihat hasil cetak atau print out dari masing-masing peserta. Sebelumnya dengan mengamati dan melakukan tanya jawab kepada peserta pelatihan, diketahui bahwa pengetahuan dan pemahaman mereka terhadap desain grafis dengan menggunakan komputer sangat minim sekali atau bahkan ada yang belum tahu sama sekali. Oleh karena itu dengan membandingkan hasil cetak/print out desain setelah pelatihan dengan pengamatan awal sebelum pelatihan maka dapat disimpulkan bahwa peserta pelatihan telah memahami bagaimana mendesain batik dengan menggunakan photoshop.

Peserta dalam program kegiatan PPM ini adalah siswa-siswi SMK Negeri 5 Kota Bengkulu tahun 2014, yang berjumlah kurang lebih 25 orang. Berdasarkan evaluasi dalam 
pelaksanaan program kegiatan PPM ini ternyata diperoleh hasil bahwa peserta yang hadir dalam program pelatihan telah mampu mendesain batik dengan menggunakan program photoshop. Program pelaksanaan kegiatan PPM ini dirancang dengan menggunakan metode praktek secara langsung menggunakan komputer dengan didukung software photoshop.

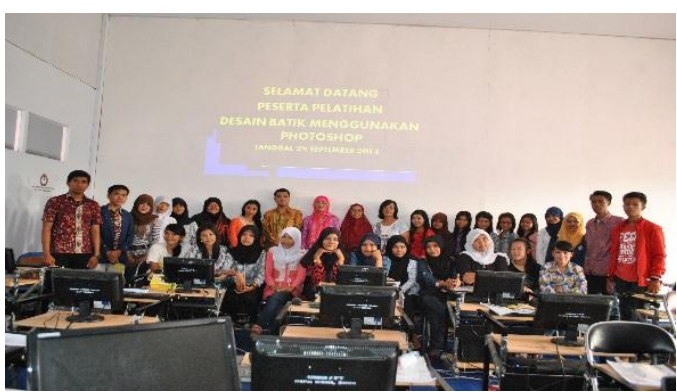

Foto bersamakegiatan Pelatihan

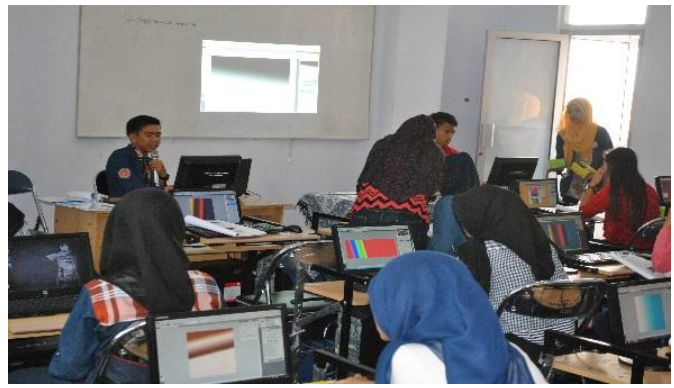

Pemateri memberikan pelatihan

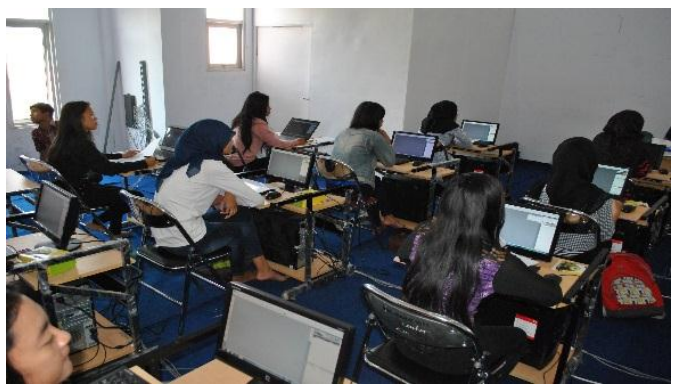

Antusias peserta mengikuti pelatihan

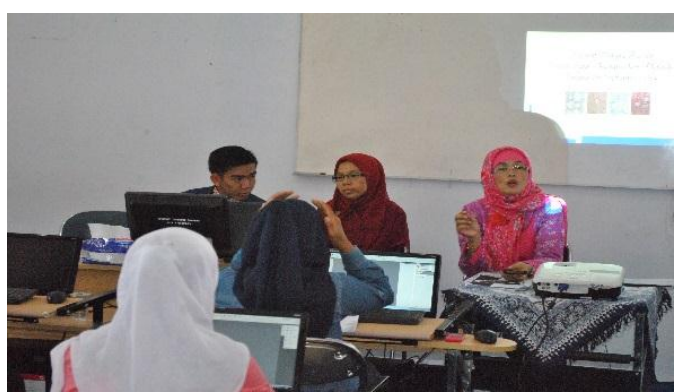

Ketua Tim membuka kegiatan Pelatihan

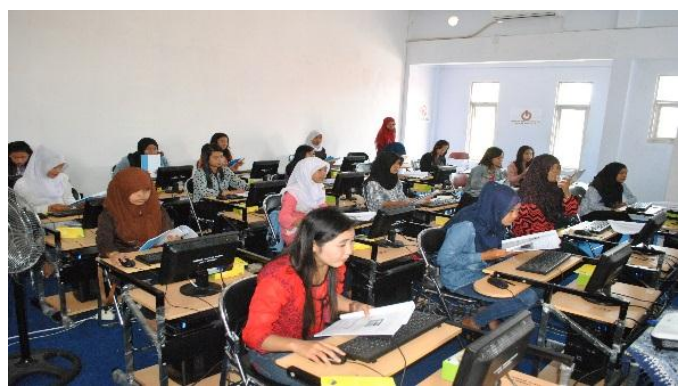

Peserta aktif mengikuti pelatihan

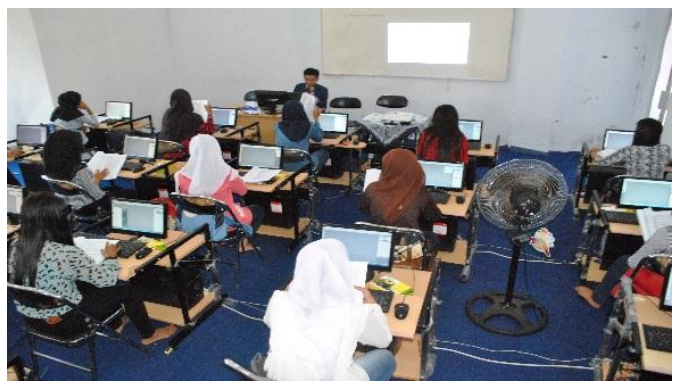

25 orang peserta sedang melakukan praktek

Gambar 1. Pelaksanaan Pelatihan Desain Batik Menggunakan Adobe Photoshop Terhadap Siswa-Siswi SMK Negeri 5 Kota Bengkulu

Animo, antusiasme dan kepuasan dari peserta yang hadir dalam program kegiatan PPM ini ternyata dapat dirasakan juga oleh tim anggota PPM, hal ini terbukti dengan peserta yang hadir sesuai dengan jadwal yaitu pukul 08.00 WIB. Peserta dengan tertib mengikuti seluruh rangkaian acara dari awal sampai akhir. Selain itu banyaknya interaksi diskusi dan tanya jawab yang terjadi pada setiap sesi materi yang disampaikan 
menunjukkan bahwa peserta pelatihan berminat untuk dapat menguasai materi yang diberikan. Materi dan metode yang diajarkan cukup mudah dipahami oleh peserta pelatihan.

\section{KESIMPULAN}

Pengabdian Penerapan IPTEKS Batik Design Training Sebagai Upaya Pembekalan Soft Skill di Bidang Desain Grafis Terhadap Siswa-Siswi SMK Negeri 5 Kota Bengkulu telah terlaksana dengan baik. Metode pelatihan dengan praktek langsung menggunakan komputer membantu peserta dalam kemudahan memahami fungsi-fungsi dasar yang ada pada software photoshop sebagai alat bantu mendesain batik. Dari evaluasi pelatihan disimpulkan bahwa peserta pelatihan telah memahami fungsi-fungsi dasar yang terdapat pada photoshop, hal ini dibuktikan dengan hasil cetak/print out desain batik yang telah dibuat oleh setiap peserta. Evaluasi pelatihan diperoleh dengan membandingkan tingkat pengetahuan peserta terhadap software photoshop sebelum dan setelah mengikuti.

\section{DAFTAR PUSTAKA}

Anonim, 2013, Katalog Pameran Tetap Bengkulu, Dinas Kebudayaan dan Pariwisata Pemerintah Provinsi Bengkulu. 